\title{
ПРИМЕНЕНИЕ ЭЛЕКТРОМАГНИТНОГО ГЕОТЕРМОМЕТРА ДЛЯ РЕШЕНИЯ ЗАДАЧ ГЕОТЕРМИИ И РАЗВЕДКИ ГЕОТЕРМАЛЬНЫХ РЕСУРСОВ
}

Спичак В. В., Захарова О. К.

\begin{abstract}
Аннотация
В статье представлен обзор последних достижений в области применения электромагнитного геотермометра для решения задач геотермии и разведки геотермальных ресурсов. Анализируются особенности моделей температуры известных геотермальных областей Лардерелло-Травале (Италия), Сульц-су-Форе (Франция) и Хенгидль (Исландия), построенных по данным электромагнитных зондирований и геотермам из пробуренных скважин. Двумерная модель температуры, построенная вдоль магнитотеллурического профиля в геотермальной зоне Травале, позволила оконтурить потенциальный резервуар надкритических флюидов на глубинах между двумя изотермами TSCF $\sim 400^{\circ} \mathrm{C}$ и TBDT $\sim 600^{\circ} \mathrm{C}$, совпадающими с обнаруженными ранее сейсмическими отражающими горизонтами. Трехмерная модель температуры геотермального участка Хенгидль (Исландия), построенная по данным электромагнитного зондирования до глубины 20км, позволила определить местоположение высокотемпературных магматических карманов на малой глубине (2-5км), которые могут служить целями для разведки геотермальных ресурсов. Совместный анализ моделей удельного сопротивления и температуры с учетом аномалий поля силы тяжести выявил области земной коры с разными тепловыми режимами, что, в свою очередь, дало возможность объяснить наблюдаемое распределение сейсмичности не влиянием спрединга коры, а термомеханическим эффектом. Глубинная модель температур, построенная для геотермальной зоны Сульц-су-Форе (Франция) по профильным магнитотеллурическим данным и термометрии в скважинах, была использована для локализации глубинных источников тепла, а также прогноза механизма его переноса на глубинах до 8км.
\end{abstract}

\section{Ключевые слова:}

Электромагнитный геотермометр, температура, электромагнитное зондирование, источник тепла 


\title{
ПРИМЕНЕНИЕ ЭЛЕКТРОМАГНИТНОГО ГЕОТЕРМОМЕТРА ДЛЯ РЕШЕНИЯ ЗАДАЧ ГЕОТЕРМИИ И РАЗВЕДКИ ГЕОТЕРМАЛЬНЫХ РЕСУРСОВ
}

\author{
В.В. Спичак, О.K. Захарова \\ Центр геоэлектромагнитных исследований Института физики Земли РАН, г.
} Москва, г. Троицк

В статье представлен обзор последних достижений в области применения электромагнитного геотермометра для решения задач геотермии и разведки геотермальных ресурсов. Анализируются особенности моделей температуры известных геотермальных областей Лардерелло-Травале (Италия), Сульц-су-Форе (Франция) и Хенгидль (Исландия), построенных по данным электромагнитных зондирований и геотермам из пробуренных скважин. Двумерная модель температуры, построенная вдоль магнитотеллурического профиля в геотермальной зоне Травале, позволила оконтурить потенциальный резервуар надкритических флюидов на глубинах между двумя изотермами $\mathrm{T}_{\mathrm{SCF}} \sim 400^{\circ} \mathrm{C}$ и $\mathrm{T}_{\mathrm{BDT}} \sim 600^{\circ} \mathrm{C}$, совпадающими с обнаруженными ранее сейсмическими отражающими горизонтами. Трехмерная модель температуры геотермального участка Хенгидль (Исландия), построенная по данным электромагнитного зондирования до глубины 20км, позволила определить местоположение высокотемпературных магматических карманов на малой глубине (25км), которые могут служить целями для разведки геотермальных ресурсов.

Совместный анализ моделей удельного сопротивления и температуры с учетом аномалий поля силы тяжести выявил области земной коры с разными тепловыми режимами, что, в свою очередь, дало возможность объяснить наблюдаемое распределение сейсмичности не влиянием спрединга коры, а термомеханическим эффектом. Глубинная модель температур, построенная для геотермальной зоны Сульцсу-Форе (Франция) по профильным магнитотеллурическим данным и термометрии в скважинах, была использована для локализации глубинных источников тепла, а также прогноза механизма его переноса на глубинах до 8км.

Электромагнитный геотермометр, температура, электромагнитное зондирование, источник тепла, надкритические флюиды, скважины. 


\title{
APPLICATION OF THE ELECTROMAGNETIC GEOTHERMOMETER IN GEOTHERMICS AND GEOTHERMAL EXPLORATION
}

\author{
V.V. Spichak, O.K. Zakharova \\ Geoelectromagnetic Research Centre IPE RAS, \\ Moscow, Troitsk
}

The paper presents a review of recent advances in using of electromagnetic geothermometer in geothermics and geothermal exploration. Characteristic features of temperature models of the well known geothermal areas Larderello-Travale (Italy), Soultzsous-Forêts (France) and Hengill (Iceland), constructed from electromagnetic sounding data are analyzed. 2D temperature model built along a magnetotelluric profile crossing Travale (Italy) geothermal system enabled to constrain the location of potential supercritical reservoir by two isotherms $\mathrm{T}_{\mathrm{SCF}} \sim 400^{\circ}$ and $\mathrm{T}_{\mathrm{BDT}} \sim 600^{\circ}$ coinciding with seismic reflection horizons, detected earlier. 3D temperature model of the Hengill (Iceland) geothermal area built up to the depth of $20 \mathrm{~km}$ from electromagnetic sounding data enabled to explain location of magma pockets at shallow depth (2-5km). Joint analysis of the resistivity and temperature models taking into account gravity anomalies allowed to distinguish domains in the crust with different thermal regimes, which, in turn, explains the observed seismicity structure by thermo-mechanical rather than by crust spreading effect. Deep temperature model built in the Soultz-sous-Forêts (France) from the profile magnetotelluric data and temperature well logs was used for locating deep heat sources and predicting heat transfer mechanism at depth up to $8 \mathrm{~km}$.

Electromagnetic geothermometer, temperature, electromagnetic sounding, heat source, supercritical fluids, boreholes.

\section{ВВЕДЕНИЕ}

Оценки температуры в недрах Земли обычно основываются на ее измерениях в скважинах или на данных о градиенте теплового потока. В первом случае проводится пространственная экстраполяция термограмм, измеренных в скважинах, как правило, нерегулярно расположенных на поверхности, что часто приводит к существенным ошибкам. Во втором случае построение моделей температуры основано на предположениях о стационарности тепловых потоков на боковых гранях области 
моделирования и знании / предположении о значениях теплового потока на ее нижней и верхней границах (см., например, [Шварцман, 1992; Дучков и др., 2001; Подгорных и др., 2001; Хуторской и др., 2008; Ollinger et al., 2010]). Поскольку эти значения известны, как правило, очень приблизительно (особенно на нижней границе), то построение соответствующих моделей температуры на этой основе часто сопряжено с существенными погрешностями.

Альтернативный подход мог бы состоять в оценке температур земных недр с помощью так называемых “косвенных геотермометров”, основанных на геологических [Harvey, Browne, 2000], геохимических [Kharaka, Mariner, 1989; Arnorrson, Gunnlaugsson, 1985], изотопных [Поляк и др., 1979; Polyak, Tolstikhin, 1985] данных, собранных на поверхности. Они являются полезными инструментами для оценки температуры на характерных глубинах (в реперных точках) и, соответственно, могут использоваться для уменьшения неопределенности при построении моделей температуры. Однако, они не могут служить ни для построения таких моделей, ни для интерполяции / экстраполяции температуры по имеющимся термограммам.

Зависимость удельной электропроводности от температуры (см., например, обзоры [Спичак, 2008; Spichak, Manzella, 2009]) может дать дополнительную информацию, особенно полезную при оценке температуры в активных регионах. Геоэлектрические данные помогают интерпретировать температурные профили на основе предположений о теплопроводности и механизмах теплогенерации [Cermak, Lastovickova, 1987]. Оценивая удельную электропроводность в Земле на основании данных электромагнитной индукции, можно сделать прямую количественную оценку значений температуры в тех же точках, используя эмпирические формулы. Лабораторные измерения удельной электропроводности как функции температуры показали, что она, вообще говоря, растет с ее ростом. Однако, диапазоны и скорость роста для разных пород отличаются, так как удельная электропроводность чувствительна также к таким факторам, как степень водонасыщения пород, содержание глинистых минералов, пористости и других микроструктурных параметров (см., например, [Roberts, 2002]).

Усредненные кривые удельной электропроводности как функции температуры для разных типов пород, а также оценки имеющих место механизмов электропроводности, использовались для построения региональных кривых температуры [Adam, 1976; Shankland, Ander, 1983; Cermak, Lastovickova, 1987; Дмитриев и др., 1988]. Однако для оценки температуры на сравнительно небольших 
глубинах (например, до 3-7 км) требуется повышенная точность, какой трудно ожидать от подходов, упомянутых выше.

Принципиально другой подход к оценке температуры земных недр может быть основан на использовании ее неявной связи с удельной электропроводностью, которая в данном случае выступает как информационный прокси-параметр. На этой основе в работе [Спичак и др., 2007] был предложен электромагнитный (ЭМ) геотермометр. Он не требует априорных знаний или предположений о механизмах электропроводности в земной коре и свободен от отмеченных выше недостатков других косвенных геотермометров.

За прошедшее с тех пор время этот подход использовался для оценки температуры на глубинах ниже забоя скважин [Spichak, Zakharova, 2009; Спичак, Захарова, 2018], а также в пространстве между скважинами [Spichak et al., 2011]. Разработанные методики и технологии [Спичак, Захарова, 2006, 2019] позволили построить двумерные и трехмерные модели температуры ряда регионов мира. С помощью разработанной научно-методической базы [Спичак, Захарова, 2013; Spichak, Zakharova, 2015], можно не только строить модели температуры, но и делать важные выводы о характере идущих в земной коре физико-механических процессов. В настоящем обзоре на примере известных геотермальных регионов мы рассмотрим применение ЭМ геотермометрии для определения местоположения глубинных источников тепла, оценки преобладающего механизма переноса тепла на больших глубинах, локализации надкритических геотермальных резервуаров.

\section{ОСНОВЫ МЕТОДА}

Оценку параметров в межскважинном пространстве обычно выполняют путем линейной интерполяции или с помощью геостатистических инструментов, основанных на пространственном статистическом анализе аппроксимированной функции; наиболее часто применяется метод кригинга. Используя профили удельного электрического сопротивления, полученные по данным электромагнитного зондирования, можно уменьшить погрешности интерполяции, поскольку в этом случае база данных расширяется за счет добавления новых данных (удельного сопротивления), некоторым образом связанных с температурой. В отличие от других косвенных геотермометров, этот подход позволяет оценивать температуру в заданных местоположениях недр, что делает его незаменимым инструментом при поиске, разведке и эксплуатации геотермальных резервуаров. 
Технология прогноза температуры с помощью электромагнитного геотермометра состоит из следующих шагов [Спичак, Захарова, 2013]:

- проведение электромагнитного зондирования (с естественными или контролируемыми источниками поля) участка, где требуется построить модель температуры;

- построение модели удельного сопротивления / электропроводности этого участка;

- калибровка ЭМ геотермометра на геотермах из имеющихся скважин (с помощью обучения искусственной нейросети “с учителем” на соответствии значений удельного сопротивления и температуры в одних и тех же точках);

- прогноз температуры с помощью ЭМ геотермометра (обученной нейросети).

В работе [Spichak et al., 2011] было показано, что точность оценки температуры в межскважинном пространстве определяется преимущественно четырьмя факторами, связанными с характеристиками пространства между местом, где оценивается температурный профиль, и пунктом ЭМ зондирования: наличие разломов, потоков метеорных и подземных вод, расстояния между пунктами и латеральная геологическая неоднородность (хотя последний из названных факторов оказывает меньшее влияние, если применяются адекватные алгоритмы инверсии ЭМ данных). Поэтому априорные знания о геологии и гидрологических условиях района работ могут помочь в правильном размещении ЭМ датчиков по отношению к областям, где предполагается прогнозировать температуру, и, тем самым, снижении погрешности оценок.

Разработаны оптимальные методики калибровки косвенного электромагнитного геотермометра в различных геологических условиях [Spichak et al., 2011; Spichak and Zakharova, 2012]. В частности, показано, что с помощью ЭМ геотермометра, калиброванного по 6-8 термограммам, можно снизить среднюю относительную погрешность оценки температуры до 12\%. Априорные знания о геологии и гидрологических условиях района работ могут помочь в правильном размещении ЭМ датчиков по отношению к участкам, где предполагается прогнозировать температуру, и, тем самым, снизить погрешность ее оценки до 5-6\%.

Особое внимание уделялось применению косвенного ЭМ геотермометра для экстраполяции температуры на глубину [Spichak and Zakharova, 2009]. Результаты, полученные на Бищкекском геодинамическом полигоне северного Тянь-Шаня, указывают на то, что точность экстраполяции температур зависит, главным образом, от 
соотношения между длиной ствола скважины, где имеется геотерма, и глубиной экстраполяции. Так, при экстраполяции на глубину вдвое большую, чем глубина забоя скважины, относительная погрешность может составлять менее 2\% [Спичак, Захарова, 2019]. Такой результат позволяет значительно увеличить глубинность косвенной оценки температур в недрах Земли на основе имеющихся геотерм. На его основе в работах [Spichak, 2013, 2014] предложена новая концепция прогноза температуры во время бурения (Forecasting While Drilling - FWD), основанная на использовании результатов предварительной 3D электромагнитной разведки участка и каротажа во время бурения.

ЭМ геотермометрию успешно применялась для оценки глубинных температур в геотермальных областях Сульц-су-Форе во Франции [Spichak et al., 2015], Хенгидль в Исландии [Spichak et al., 2013] и Травале в Италии [Спичак, Захарова, 2015; Спичак, 2019]. Ниже мы кратко рассмотрим некоторые возможности, которые открываются благодаря полученным результатам.

\section{ОКОНТУРИВАНИЕ РЕЗЕРВУАРА НАДКРИТИЧЕСКИХ ФЛЮИДОВ}

Часто возникает необходимость определить тип теплоносителя, который циркулирует в геотермальной системе. В частности, сложно отличить горячие водные и газообразные флюиды только по разрезам удельного электрического сопротивления и/или сейсмических скоростей, не имея априорной информации, которую можно получить из геологических и геохимических исследований, каротажных данных и т.д. Однако, даже совместный анализ данных удельного электрического сопротивления и сейсмических скоростей не всегда обеспечивает достаточно информации для того, чтобы сделать достаточно обоснованные выводы о типе геотермальных флюидов (см., например, работу [Jousset et al., 2011]). С другой стороны, построение модели температуры для изучаемого участка может предоставить необходимую для этого информацию.

Для иллюстрации можно привести пример геотермальной области ЛардереллоТравале (Италия) (рис. 1). С целью лучшего понимания геотермальных условий в регионе Gola et al. [2017] систематизировали имеющиеся структурные, геологические, геохимические, геохронологические, петрологические и геофизические данные, опубликованные многочисленными исследователями этой области за последние 30 лет. Согласно этой работе, в районе существует два основных геотермальных резервуара: «приповерхностный», расположенный в эвапоритово-карбонатных комплексах (средняя глубина $0,7-1,0$ км, температура от $150{ }^{\circ} \mathrm{C}$ до $260{ }^{\circ} \mathrm{C}$ ) и «глубокий», расположенный в 
метаморфической части разреза и гранитоидах неогенового возраста (глубина 2,5 - 4,0 км, температура от $300^{\circ} \mathrm{C}$ до $350^{\circ} \mathrm{C}$ ) [Bertani et al., 2005; Romagnoli et al., 2010]. В обоих резервуарах циркулируют флюиды преимущественно метеорного происхождения, находящиеся в парообразном состоянии [Celati et al., 1991]. Подпитка метеорными водами происходит через выходящие на поверхность карбонатные формации; кроме того, также предполагается приток флюидов по латерали из региональных водонапорных горизонтов, окружающих гидротермальные резервуары (вероятно, индуцированный текущей эксплуатацией скважин [Romagnoli et al., 2010; Celati et al., 1991].

B результате 2D и 3D сейсморазведочных работ, проведенных в прошлые десятилетия, были получены данные, которые свидетельствуют о существовании двух заметных сейсмических маркеров - горизонта $H$ и горизонта $K$ (показаны на рис. 2) - с перерывами прослеживаемыми на всей площади. Данные бурения показали, что в некоторых случаях горизонт $Н$ соответствует уровню термо-метаморфического ореола неогеновых гранитоидов [Bertini et al., 2006]; с этого уровня при помощи множества скважин велась добыча перегретого пара. Более глубокий горизонт $K$ имеет похожую динамическую картину, но местами демонстрирует отклонения, характерные для так называемых «ярких пятен», и по сравнению с горизонтом $H$ имеет более непрерывную пространственную протяженность. Начиная с 1983 г., характер и происхождение этих горизонтов являются предметом обсуждения [Batini et al., 1983; Cameli et al., 1993; Liotta and Ranalli, 1999], поскольку они не были вскрыты скважинами (кроме, возможно, скважины San Pompeo 2). Термобарические условия, экстраполированные на этот уровень ( $\left.\mathrm{P} \approx 30 \mathrm{MПа} \mathrm{и} \mathrm{T}>400{ }^{\circ} \mathrm{C}\right)$, похоже, не соответствуют глубинному геотермальному резервуару, который до сих пор эксплуатируется и характеризуется давлением ниже гидростатического (это давление контролируется текущим состоянием перегретого пара [Romagnoli et al., 2010]).

Упомянутые выше неопределенности можно снизить за счет привлечения моделей удельного электрического сопротивления и температуры для данной площади. Пушкаревым [Pushkarev, 2007] была построена 2D модель удельного электрического сопротивления вдоль профиля АА’ (рис. 3, положение профиля показано на рис. 1б). На рис. 3 видно, что удельное электрическое сопротивление демонстрирует неоднородные характеристики, и это согласуется с сильной сейсмической анизотропией (16\%) этого участка, выявленной в работе [Piccinini and Saccorotti, 2018]. В целом, значения удельного сопротивления изменяются от 10 до 100 Омм, что указывает на возможное присутствие флюидонасыщенных пород. 
Спичак [2019] использовал ЭМ геотермометр для построения модели температур вдоль того же профиля (рис. 4) на основании упомянутой выше модели удельных электрических сопротивлений и имеющихся на этой площади данных термокаротажа. Анализ построенной модели позволяет объяснить некоторые особенности, которые не удалось объяснить в рамках предыдущих концептуальных моделей этой геотермальной зоны (см., например, [Manzella et al., 2006]). В частности, обращает на себя внимание, что изотерма $\mathrm{T}_{\mathrm{SCF}}=374^{\circ} \mathrm{C}$, соответствующая температуре образования сверхкритических флюидов (Super Critical Fluids), практически совпадает с верхним отражающим горизонтом $H$ (на рис. 2 показано его местоположение), тогда как изотерма $\mathrm{T} \approx 600^{\circ} \mathrm{C}$, соответствующая солидусу влажных гранитов, соответствует местоположению нижнего отражающего горизонта $K$.

Эти результаты можно интерпретировать следующим образом. Нижний отражающий горизонт К соответствует переходу от охлаждения частично расплавленной магматической интрузии (на глубине более 5000 м), находящейся в пластическом состоянии, к хрупкой коре (выше изотермы $\mathrm{T}_{\mathrm{BDT}} \approx 600^{\circ} \mathrm{C}$, где $\mathrm{BDT}$ Brittle-Ductile Transition), насыщенной вязкой смесью глубинных магматогенных вод, которые мигрировали вверх на приповерхностные уровни, продуктов взаимодействия воды и горных пород, и метеорных вод [Brogi et al., 2003], которые находятся в надкритическом состоянии под давлением более 220 Кбар при температурах от $\mathrm{T}_{\text {scғ }}$ до $\mathrm{T}_{\mathrm{BDT}}$. Скачок сейсмических скоростей на нижнем отражающем горизонте К может быть связан с резким уменьшением сдвиговой жесткости при переходе от хрупкой среды к пластичной [Carzione and Poletto, 2013].

На сравнительно небольших глубинах (менее 2 км) снижение давления и температуры соответствует переходу от надкритических флюидов, расположенных ниже местоположения изотермы $\mathrm{T}_{\mathrm{scF}}$, к перегретой смеси пара и газа. Однако, этот переход не настолько резкий, как переход между хрупкими и пластичными горными породами на глубине изотермы $\mathrm{T}_{\mathrm{BDT}}$. Соответственно, верхний отражающий горизонт, разделяющий области надкритических флюидов с температурой выше $\mathrm{T}_{\mathrm{scF}}$ и сильно трещиноватые горные породы, содержащие газ и пар, имеет прерывистый характер. Другой важный вывод состоит в том, что вместо двух геотермальных резервуаров, о которых говорили ранее на основании интерпретации только электромагнитных и сейсмических разрезов (см., например, статью [Gola et al., 2017] и ссылки в ней), повидимому, следует говорить об одном глубинном надкритическом резервуаре и связанном с ним канале переноса горячего пара к поверхности (см. область под 
пунктами магнитотеллурического зондирования (МТ3) k5-с7 на глубинах 0-2 км на рис. 4).

\section{ИСТОЧНИКИ ТЕПЛА И СЕЙСМИЧНОСТЬ}

Применение косвенного ЭМ геотермометра позволяет построить для района работ трехмерную модель температуры, которая может стать многоцелевой базой данных для дальнейшего анализа с точки зрения геотермальных условий. В работе [Spichak et al., 2013] была построена модель высокотемпературной геотермальной области Хенгидль в Исландии, которая использовалась для обнаружения источников тепла и объяснения структуры сейсмичности.

Область Хенгидль, расположенная на юго-западе Исландии, находится на пересечении Западной вулканической зоны (WVZ), рифта полуострова Рейкьянес (RPR) и Южно-исландской сейсмической зоны (SISZ) (рис. 5, верхняя панель). Вулканический комплекс Хенгидль включает в себя несколько взаимосвязанных геотермальных полей, находящихся по разные стороны от горы Хенгидль (в нижней части рис. 5 помечена буквой H): область Хверагерди (Hv) на юго-востоке, область Несъяведлир (Ne) на северо-востоке и область Хедлисхейди (Не) на юго-западе.

В целом, в рассматриваемой области находится четыре центра вулканической активности (рис. 5, нижняя панель): упомянутая выше область Хенгидль, а также области Гренсдалур, Хромундартиндур и Хусмули. Вулканический комплекс Хенгидль содержит активный центральный вулкан и систему трещин северо-северо-восточного простирания (рис. 6). Вторичный структурно-тектонический тренд, перпендикулярный преобладающему ССВ-ЮЮЗ тренду проявлений коровой аккреции, развит в зоне, соединяющей центры вулканических комплексов Хенгидль и Гренсдалур и простирается вдоль структуры Олькельдухалс (рис. 5, нижняя панель).

Спичак и др. [2012] построили 3D модель удельного электрического сопротивления геотермальной области Хенгидль до глубины 20 км (рис. 7). На основании этой модели авторы показали, что источником тепла в верхней коре этого региона может быть восходящий поток материала с высокой проводимостью с глубин более 20 км, его скопление в подземных резервуарах и дальнейшее распространение в реологически ослабленном слое на глубинах 5-15 км. Как и предполагалось ранее, полученные результаты подтвердили мантийное происхождение источников тепла в этом районе. При этом в диапазоне глубин от 10 до 25 км не оказалось непрерывного хорошо проводящего слоя с удельными сопротивлениями ниже 10 Омм, который 
предполагался там ранее по результатам отдельных профильных МТЗ. Вместо этого были обнаружены локальные хорошо проводящие участки, связанные друг с другом и по горизонтали, и по вертикали.

Анализ трехмерной модели температуры, построенной в работе [Spichak et al., 2013] (см. горизонтальные и вертикальные срезы температуры на рис. 8 и 9, соответственно), позволил ответить на вопросы, не находившие ответов в рамках предыдущих концептуальных моделей. Согласно этой модели фоновая температура исландской коры на глубине менее 20 км составляет не более $400^{\circ} \mathrm{C}$. На нее наложена сеть взаимосвязанных высокотемпературных каналов с низким удельным сопротивлением, которые пронизывают кору, в основном, на уровне 10-15 км и уходят корнями на глубину более 20 км.

Соответственно, можно предположить, что вероятные источники тепла, подпитывающие геотермальную систему, это интрузии горячей частично расплавленной магмы, поднимающейся из мантии вверх по разломам и трещинам. В частности, был сделан вывод, что источником обнаруженных в работе [Elders and Fridleifsson, 2010] на глубине 2 км аномально высоких температур (1100C) может быть расплавленная жидкая магма с температурой выше ликвидуса, поднимающаяся из мантии и, в конечном счете, скапливающаяся в магматических “карманах” на приповерхностных глубинах (2-5 км) (рис. 9). Сопоставление вертикальных разрезов температур и распределений гипоцентров землетрясений (см. их местоположение на рис. 9) показало, что все они расположены в областях, где температура не превышает $400^{\circ} \mathrm{C}$, что соответствует солидусу габбро в богатой силикатами исландской коре.

Совместный анализ моделей температуры и удельного электрического сопротивления с учетом данных гравиметрии позволил разделить местоположения реликтовой и активной частей вулканического геотермального комплекса. На рис. 10 представлена карта поля силы тяжести в редукции Буге, на которой четыре соседних участка (их местоположения показаны в нижней части рис. 5) соответствуют областям в земной коре с разными тепловыми режимами: в крупных массивах Хусмули (I) и Гренсдалур (III) затвердевающая магма остывает, тогда как в более активных областях Несъяведлир (II) и Хедлисхейди (IV) происходит движение вверх частично расплавленной магмы или горячих флюидов. Они разделены глубинным субмеридиональным разломом и поперечной тектонической структурой Олькельдухалс (обозначены пунктирными линиями на рис. 10).

Глубинный разлом прослежен на горизонтальных срезах удельного электрического сопротивления (рис. 7) и температуры (рис. 8). Он совпадает с 
предполагаемым местоположением трансформного разлома субмеридионального простирания, который проходит в южной части региона (рис. 6). Это, в свою очередь, объясняет наблюдаемое распределение сейсмичности различными термальными режимами в четырех соседних частях области, разделенных меридиональным разломом, который ограничен меридианами $21.31^{\circ}$ и $21.33^{\circ}$ ЗД и диагональной полосой 3СЗ-ВЮВ направления, проходящей ниже тектонической структуры второго порядка Олькельдухалс.

\section{ОЦЕНКА ПРЕОБЛАДАЮЩЕГО МЕХАНИЗМА ТЕПЛОПЕРЕНОСА И ПУТЕЙ ЦИРКУЛЯЦИИ ФЛЮИДОВ}

Спичак и др. [Spichak et al., 2015] применили электромагнитный геотермометр для оценок глубинных температур в геотермальной области Сульц-Су-Форе во Франции по данным магнитотеллурического зондирования вдоль профиля АВ (рис. 11). Тестирование точности оценки температуры, проводившееся путем сопоставления профиля прогнозных температур и термограммы из самой глубокой скважины, показало, что относительная ошибка прогноза температуры может быть менее 2\%. Было показано, что неопределенность в значениях удельного сопротивления, вызванная погрешностями инверсии МТ данных и возможным влиянием внешних факторов, оказывает очень слабое влияние на прогнозные температуры и зависит, главным образом, от соотношения глубин скважины и прогноза.

В результате 2D инверсии MT данных был построен разрез удельных сопротивлений вдоль профиля АВ (рис. 12), а применение электромагнитного геотермометра позволило построить разрез температур до глубины 5000 м (рис. 13). Он демонстрирует локальный максимум температур на больших глубинах ниже скважин GPK2 и RT1/RT3, что указывает на существование соответствующих источников тепла, расположенных на больших глубинах.

Другая примечательная особенность разреза температур заключается в синусоидальной форме изотерм в горизонтальном направлении, что подтверждает гипотезу о глубинной циркуляции флюидов в трещиноватом гранитном фундаменте Сульца [Clauser and Villinger, 1990; Le Carlier et al., 1994]. Анализ профиля температуры в скважине GPK2 на глубинах до 8000 м (рис. 14б) показал, что его поведение соответствует кондуктивному типу в диапазонах глубин 0-2000м и 3700-5000 м, тогда как в диапазонах глубин 2000-3700 и ниже 5000 м он имеет конвективный характер. 
В связи с этим следует отметить, что распространённый способ поиска путей циркуляции флюидов на больших глубинах, который основывается только на разрезах удельных электрических сопротивлений (см., например, [Manzella et al., 2006]), может приводить к неверным выводам, поскольку низкоомные аномалии удельного сопротивления могут быть вызваны несколькими причинами. Использование разрезов температур может снизить неопределенность и помочь в прослеживании флюидных потоков.

\section{ВЫВОДЫ}

Результаты применения электромагнитный геотермометра в известных геотермальных областях показали, что он может успешно использоваться для построения двумерных и трехмерных моделей температуры до глубин, ограниченных только глубинностью используемых с этой целью методов электромагнитного зондирования. Анализ построенных моделей позволяет делать выводы о доминирующих механизмах теплопроводности на больших глубинах и расположении возможных источников тепла. Исследования в исландской геотермальной зоне показали особенную полезность совместного анализа моделей удельного сопротивления, температуры и гравитационных аномалий для построения концептуальных моделей геотермальных зон.

ЭМ геотермометр может использоваться при интерполяции скважинных измерений на межскважинное пространство, а также для экстраполяции температуры ниже забоя скважин. Это обстоятельство делает его особенно привлекательным при проведении разведочных работ в геотермальной энергетике (особенно, при поисках “тепла сухих пород”, которое не обязательно сопровождается аномалиями в геофизических полях), а также при поисках углеводородов по аномалиям температуры. Применение ЭМ геотермометра в геотермальной энергетике может резко снизить затраты на разведочное бурение скважин и, за счет этого, повысить ее конкурентоспособность по сравнению с альтернативными источниками энергии.

Работа выполнена при финансовой поддержке Российского научного фонда (грант № 20-17-00155). 


\section{СПИСОК ЛИТЕРАТУРЫ}

Дмитриев В.И., Ротанова Н.М., Захарова О.К. Оценки распределения температуры в переходном слое и нижней мантии Земли по данным глобального магнитовариационного зондирования // Изв. РАН. Физика Земли, 1988, № 2, с. 3-8.

Дучков А.Д., Шварцман Ю.Г., Соколова Л.С. Глубинный тепловой поток Тянь-Шаня: достижения и проблемы // Геология и геофизика, 2001, т. 42, № 10, с. 15121529.

Подгорных Л.В., Хуторской М.Д., Грамберг И.С., Леонов Ю.Г. Трехмерная геотермическая модель Карского шельфа и прогноз нефтегазоносности // ДАН, 2001, т. 380, №2, c. 228-232.

Поляк Б.Г., Толстихин И.Н., Якуцени В.А. Изотопный состав гелия и тепловой поток - геохимический и геофизический аспекты тектогенеза // Геотектоника, 1979, № 5, c. 3-23.

Спичак В.В. Электромагнитное зондирование геотермальных зон: новые горизонты // Геофизика, 2008, №1, с. 50-67.

Спичак В.В. Электромагнитная томография земных недр. Москва, Научный мир, 2019, 374 с.

Спичак B.B., Захарова О.К. Способ оценки температуры в недрах Земли // Патент РФ № 2326413 от 1.9.2006.

Спичак B.B., Захарова O.K. Способ прогноза температуры на глубины ниже забоя скважин // Патент РФ № 2717685 от 28.5.2019.

Спичак В.В., Захарова О.К. Электромагнитный геотермометр. Москва, Научный мир, 2013, 170 с.

Спичак B.В., Захарова О.К. Построение глубинного разреза температуры в геотермальной области Травале (Италия) с помощью электромагнитного геотермометра // Физика Земли, 2015, №1, с. 90-97.

Спичак B.В., Захарова О.К. О возможности применения электромагнитного геотермометра для поиска углеводородов на глубинах ниже забоя скважин // Актуальные проблемы нефти и газа, 2018, №1(20), с. 1-7.

Спичак B.B., Захарова О.К., Рыбин А.К. О возможности бесконтактного электромагнитного геотермометра // ДАН, 2007, т. 417(3), с. 393-397. 
Шварцман Ю.Г. Тепловое поле, сейсмичность и геодинамика Тянь-Шаня // Автореферат дис. докт. геол.-мин. наук. Бишкек. ИГАНРК. 1992. - 38 с.

Batini F., Bertini G., Bottai A., Bottai A., Burgassi P.D., Cappetti G., Gianelli G., and Puxeddu M. San Pompeo 2 deep well: a high temperature and high pressure geothermal system // In: Extended Abstr. Third International Seminar on Results of EC Research and demonstration projects in the field of geothermal energy, 1983, p. 341-353.

Bellani S., Brogi A., Lazzarotto A., Liotta, D. and Ranalli, G. Heat flow, deep temperatures and extensional structures in the Larderello Geothermal Field (Italy): constraints on geothermal fluid flow // J. Volcanol. Geoth. Res., 2004, v.132, p.15-29.

Bertani R., Bertini G., Cappetti G., Fiordelisi A., and Marocco B.M. An update of Larderello-Travale / Radicondoli deep geothermal system // In: Extended Abstr.World Geothermal Congress, Antalya, Turkey, 2005.

Bertini G., Casini, Gianelli G., and Pandeli E. Geological structure of a long-living geothermal system, Larderello, Italy // Terra Nova, 2006, v.18 (3), p.163-169.

Brogi A., Lazzarotto A., Liotta D. and Ranalli G. Crustal structures in the geothermal areas of southern Tuscany (Italy): Insights from the CROP 18 deep seismic ref lection lines // J. Volcanol. Geoth. Res., 2005, v.148, p.60-80.

Carzione J.M. Poletto F. Seismic rheological model and reflection coefficients of the brittle-ductile transition // Pure Appl. Geophys., 2013, v.170, p.2021-2035.

Celati R., Cappetti G., Calore C., Grassi S., and D’Amore F. Water recharge in Larderello geothermal field // Geothermics, 1991, v.20, p.119-133.

Cermak V., Lastovickova M. Temperature profiles in the Earth of importance to deep electrical conductivity models // Pure and Applied Geophysics, 1987, v. 125, p. 255-284.

Clauser C., Villinger $\mathbf{H}$. Analysis of conductive and convective heat transfer in a sedimentary basin, demonstrated for the Rhein graben // Geophys. J. Intern., 1990, v.100, p.393-414.

Dezayes C., Genter A., Hooijkaas G. Deep-seated geology and fracture system of the EGS Soultz reservoir (France) based on recent 5km depth boreholes // In: Proc. World Geothermal Congress, Antalya, Turkey, 2005.

Elders W.A., Fridleifsson G.O. The Science Program of the Iceland Deep Drilling Project (IDDP): a study of supercritical geothermal resources // In: Expanded Abstracts of the World Geothermal Congress, Bali, Indonesia, 2010. 
Foulger G.R., Toomey D.R. Structure and Evolution of the Hengill-Grensdalur Volcanic Complex, Iceland: Geology, Geophysics, and Seismic Tomography // J.Geophys. Res. 94, 1989, v.B12, p.17511-17522.

Gola G., Bertini G., Bonini M., Botteghi S., Brogi A., De Franco R, Dini A., Donato A., Gianelli G., Liotta D., Manzella A., Montanari D., Montegrossi G., Petracchini L., Ruggieri G., Santilano A., Scrocca D., Trumpy E. Data integration and conceptual modelling of the Larderello geothermal area, Italy // Energy Procedia, 2017, v.300, p. 300-309.

Haenel R., Legrand R., Balling N., Saxov, S., Bram, K., Gable, R., Meunier, J., Fanelli, M., Rossi, A., Salmone, M., Taffi, L., Prins, S., Burley, A.J., Edmunds, W.M., Oxburgh, E.R., Richardson, S.W., Wheildon, J. Atlas of subsurface temperatures in the European Comminity // Th. Schafer Druckerei GmbH, Hannover, Germany, 1979.

Harvey C.C., Browne P.R.L. Mixed-layer clay geothermometry in the Wairakei geothermal field, New Zealand // Clay and Clay Minerals, 1995, v.39, p.614-621.

Jousset P., Haberland C., Bauer K., Arnason K. Hengill geothermal volcanic complex (Iceland) characterized by integrated geophysical observations // Geothermics, 2011, v.40, p.1-24.

Kharaka Y.K., Mariner R.H. Chemical geothermometers and their application to formation waters from sedimentary basins // In: Naeser ND, McCulloch T (eds.) Thermal History of Sedimentary Basins, S.C.P.M. Special issue, Springer Verlag, 1989, p. 99-117.

Le Carlier C., Royer J.J., Flores E.L. Convective heat transfer at Soultz-sous-Forêts geothermal site: implications for oil potential // First Break,1994, v.12 (11), p.553-560.

Manzella A., Spichak V., Pushkarev P., Sileva D., Oskooi B., Ruggieri G. and Sizov Yu. Deep fluid circulation in the Travale geothermal area and its relation with tectonic structure investigated by a magnetotelluric survey // In: Expanded Abstracts of the 31th Workshop on Geothermal Reservoir Engineering, Stanford University, USA, 2006.

Ollinger D., Baujard C., Kohl T. and Moeck I. 3-D Temperature Inversion Derived From Deep Borehole Data in the Northeastern German Basin // Geothermics, 2010, v. 39, p. 46-58.

Piccinini D., Saccorotti G. Observation and analysis of shear wave splitting at the Larderello-Travale geothermal field, Italy // J. Volcan. Geoth. Res., 2018, v.363, p.1-9.

Polyak B.G., Tolstikhin I.N. Isotopic composition of the Earth's helium and the motive forces of tectogenesis // Chem. Geology, 1985, v. 52, p. 9-33. 
Pushkarev P.Y. 2D resistivity model of the Travale geothermal field revealed from MT data. // In: Proc. Workshop INTAS project, Pisa, Italy, 2007.

Roberts J.J. Electrical properties of microporous rock as a function of saturation and temperature // J. Appl. Phys., 2002, v. 91, № 3, p.1687-1694.

Romagnoli P., Arias A., Barelli A., Cei M., and Casini M. An updated numerical model of the Larderello-Travale geothermal system, Italy // Geothermics, 2010, v.39, p.292313.

Shankland T., Ander M. Electrical conductivity, temperatures, and fluids in the lower crust // J. Geophys., 1983, v. 88 (B11), p.9475-9484.

Spichak V.V. A new strategy for geothermal exploration drilling based on using of an electromagnetic sounding data // In: Expanded Abstr. Int. Workshop on High Entalphy Geothermal Systems, San-Bernardino, California, 2013.

Spichak V.V. Reduce geothermal exploration drilling costs: pourquoi pas?! // In: Expanded Abstr. D-GEO-D Conference, Paris, France, 2014.

Spichak V.V., Geiermann J., Zakharova O., Calcagno P., Genter A. and Schill E. Estimating deep temperatures in the Soultz-sous-Forêts geothermal area (France) from magnetotelluric data // Near Surface Geophysics, 2015, v.13 (4), p.397- 408.

Spichak V.V., Manzella A. Electromagnetic sounding of geothermal zones // J. Appl. Geophys., 2009, v.68, p.459-478.

Spichak V.V., Zakharova O.K. The application of an indirect electromagnetic geothermometer to temperature extrapolation in depth // Geophys. Prosp., 2009, v.57, p.653664.

Spichak V.V., Zakharova O.K. The subsurface temperature assessment by means of an indirect electromagnetic geothermometer // Geophysics, 2012, v.77 (4), WB179-WB190.

Spichak V.V., Zakharova O.K. Electromagnetic geothermometry. Amsterdam, Elsevier, 2015, 183 p.

Spichak V.V., Zakharova O.K., Goidina A.G. A new conceptual model of the Icelandic crust in the Hengill geothermal area based on the indirect electromagnetic geothermometry // J. Volcanol. Geoth. Res., 2013, v.257, p. 99-112.

Spichak V.V., Zakharova O.K., Rybin A.K. Methodology of the indirect temperature estimation basing on magnetotelluruc data: northern Tien Shan case study // J. Appl. Geophys., 2011, v.73, p.164-173. 
Stefansson R., Gudmundsson J.B., Roberts M.J. Long-term and short-term earthquake warnings based on seismic information in the SISZ // In: VeðurstofaÍslands Greinargerð, Icelandic Meteorological Office, Rep. 06006, 53pp. Reykjavik, 2006.

Фorbergsson G., Magnusson I., Gunnarsson A., Johnsen G., Bjornsson A. Geodetic and Gravity Surveys in the Hengill area 1982 and 1983 // Orkustofnun Report OS84003/VOD-03 B. 1984. Reykjavik, Iceland (in Icelandic), 58 p. 


\section{Подрисуночные подписи}

Рис. 1. а - упрощенная тектоническая схема региона и его расположение; б- упрощенная геологическая карта, на которую нанесены пункты измерения МТ данных (треугольники) и секущий МТ профиль A-A’ [Brogi et al., 2005; Manzella et al., 2006].

Рис. 2. Геологический разрез вдоль профиля А-А', показанного на рис. 16 [Bellani et al., 2004]. Рис. 3. Разрез удельного сопротивления вдоль профиля АА' [Pushkarev, 2007],

Рис. 4. Температурный разрез вдоль МТ профиля АА', построенный с помощью ЭМ геотермометра (модифицировано по [Спичак, Захарова, 2015].

Рис. 5. Верхняя панель: расположение изучаемой области; нижняя панель: схематическая тектоническая карта тройного узла Хенгидль [Foulger, Toomey, 1989]. Толстыми линиями показаны контуры зон извержений/трещин, простирающихся в направлении ССВ. Штриховыми линиями оконтурены 4 центра геотермальной активности. Точки показывают расположение фумарол на поверхности. Линия, связывающая вулканы Хенгидль и Гренсдалур, является осью поперечной тектонической структуры, вдоль которой мигрировал вулканизм.

Рис. 6. Плотность эпицентров сейсмических событий, произошедших за период с 1991 по 2001гг., и трансформные тектонические линеаменты (жирные светлые линии), выявленные на основании общего распределения сейсмичности. Тонкие темные линии - разломы и трещины, картируемые на поверхности [Stefansson et al., 1993].

Рис. 7. Объемная модель сопротивления, построенная с помощью совместной нейросетевой инверсии данных ЗСБ и МТЗ [Спичак и др., 2012].

Рис. 8. Срезы температуры на разных глубинах [Spichak et al., 2013]. Вертикальная штриховая линия показывает проекцию на поверхность глубинного скачка температуры; диагональная штриховая линия показывает направление поперечной тектонической структуры Олькельдухалс (см. ее расположение на рис. 5).

Рис. 9. Разрезы температуры на широтах $64.02^{\circ}$ с.ш., $64.04^{\circ}$ с.ш. и $64.06^{\circ}$ с.ш. [Spichak et al., 2013]. Кружками обозначены гипоцентры землетрясений согласно работе [Jousset et al., 2011] и [Stefansson et al., 1993].

Рис. 10. Изолинии гравитационной аномалии в редукции Буге [Фorbergsson et al.. 1984]. Прямоугольник ограничивает рассматриваемую область; вертикальная штриховая линия показывает проекцию на поверхность глубинного скачка сопротивления и температуры; диагональная штриховая линия показывает направление поперечной тектонической структуры Олькельдухалс. 
Рис. 11. Местоположение геотермальной области Сульц и геология Верхне-Рейнского грабена: (1) кайнозойские осадки (2) кайнозойские вулканогенные породы (3) юрские отложения (4) триасовые отложения (5) герцинский фундамент (6) граничные разломы (7) распределение температур в ${ }^{\circ} \mathrm{C}$ на глубине 1500 м [Haenel et al., 1979]. (8) локальные термальные аномалии [Haenel et al., 1979]. На верхней вставке дан упрощенный разрез области Сульц вдоль МТ профиля АВ: (а) кайнозойские заполняющие осадки (б) мезозойские осадки (в) гранитное основание [Dezayes et al., 2005].

Рис. 12. Двумерный разрез логарифма сопротивления вдоль профиля АВ, перпендикулярного Рейнскому грабену (см. рис. 11) [Spichak et al., 2015].

Рис. 13. Температурный разрез вдоль профиля AB, показанного на рис. 11 [Spichak et al., 2015]. Треугольники показывают горизонтальные проекции местоположений скважин на этот профиль.

Рис. 14. а: 2D концептуальная геологическая модель геотермальной области Сульц-су-Форе (модифицировано из [Dezayes et al., 2005]); б: ЭМ экстраполяция температуры в скважине GPK2 на интервал глубин 5046 м - 8175 м (модифицировано из [Spichak et al., 2015]). Измеренная температура обозначена сплошной линией, а прогнозная - штриховой линией, профиль удельного сопротивления обозначен штрихпунктирной линией. Заштрихованная область ограничивает область неопределенности прогнозной температуры. 


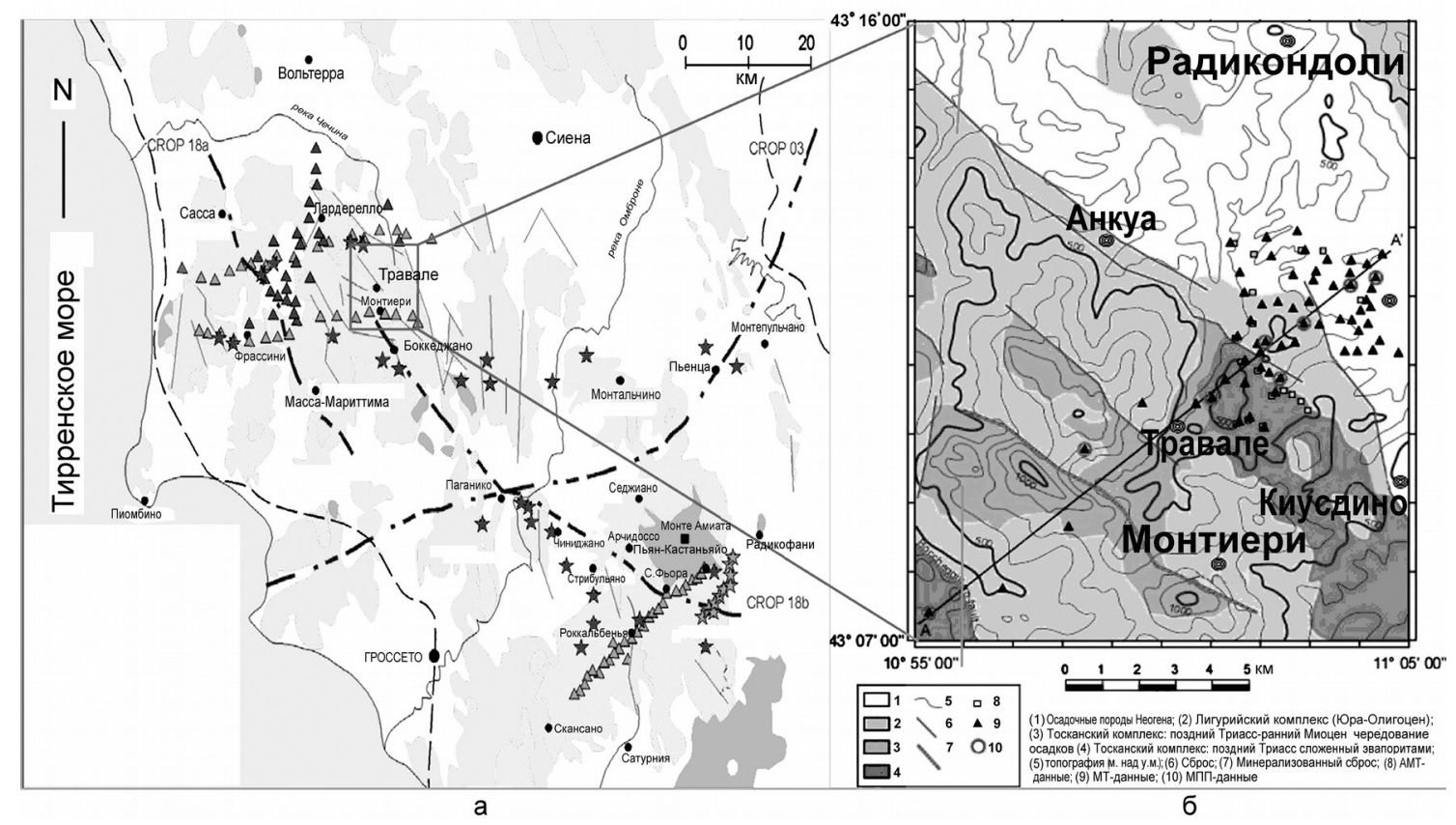




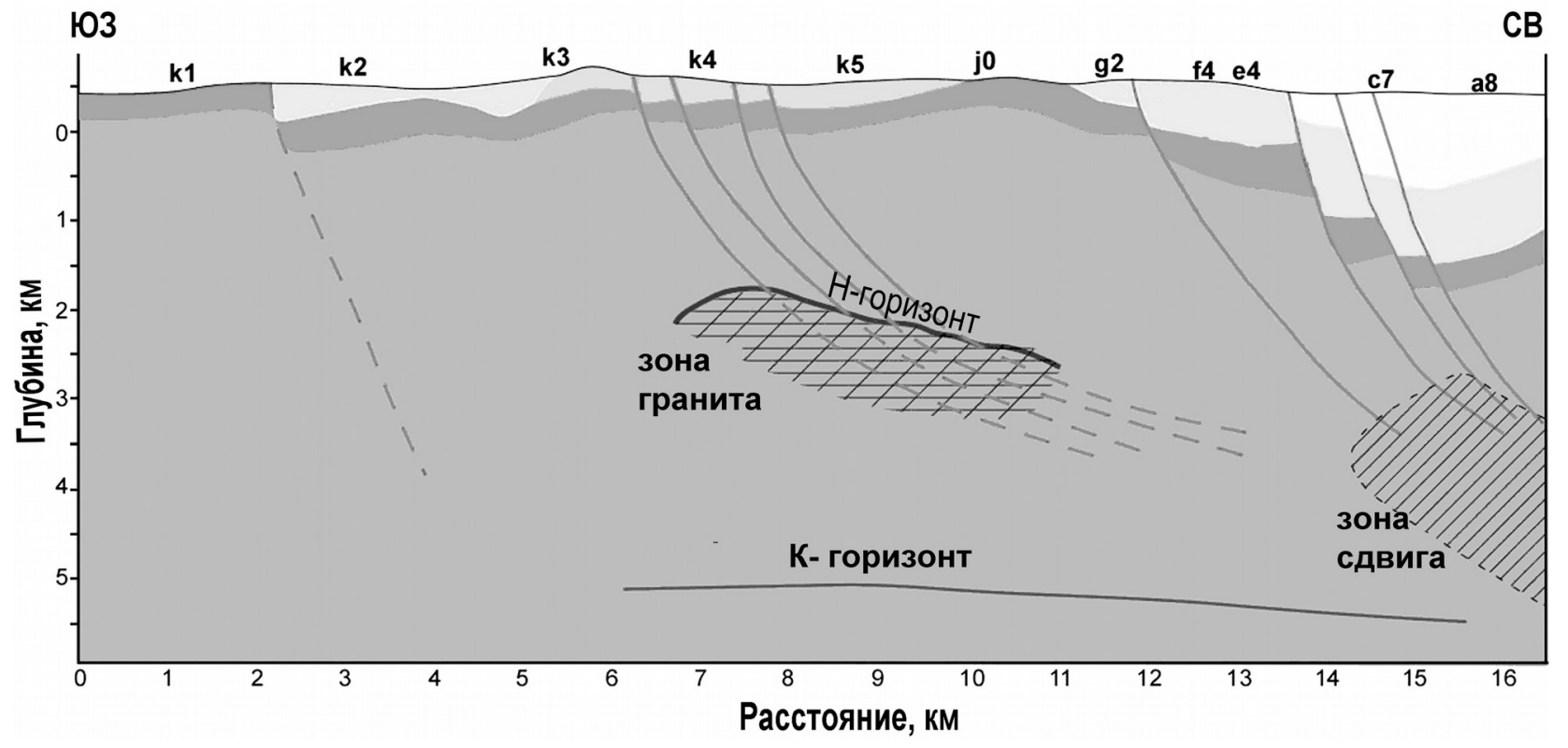




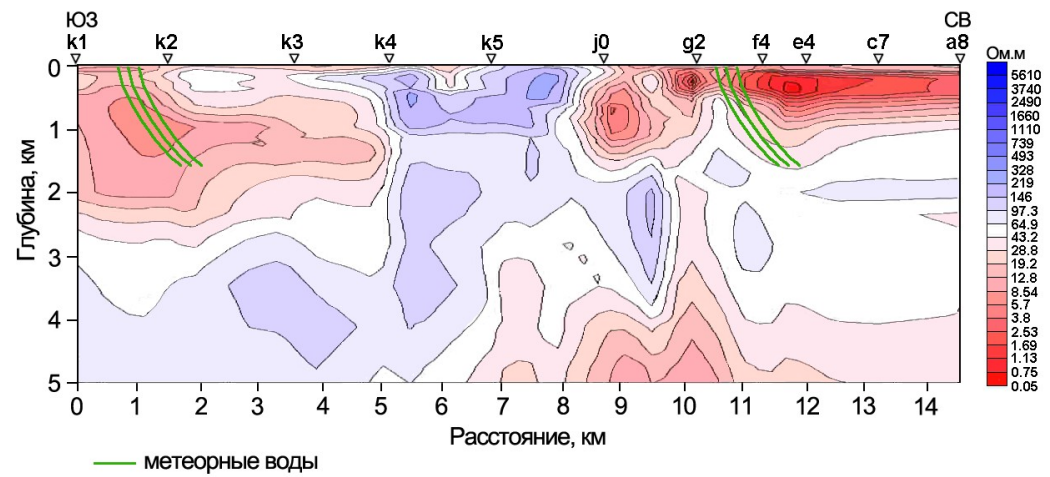




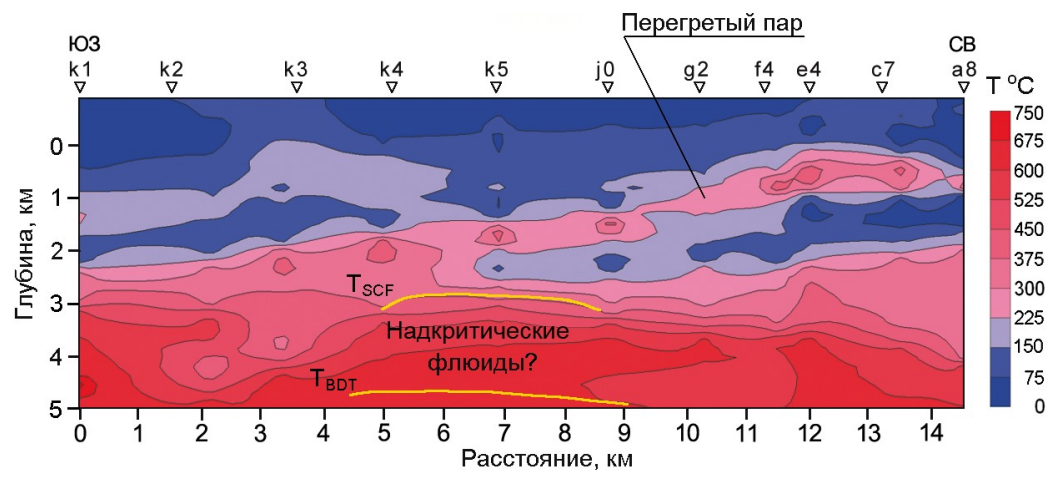




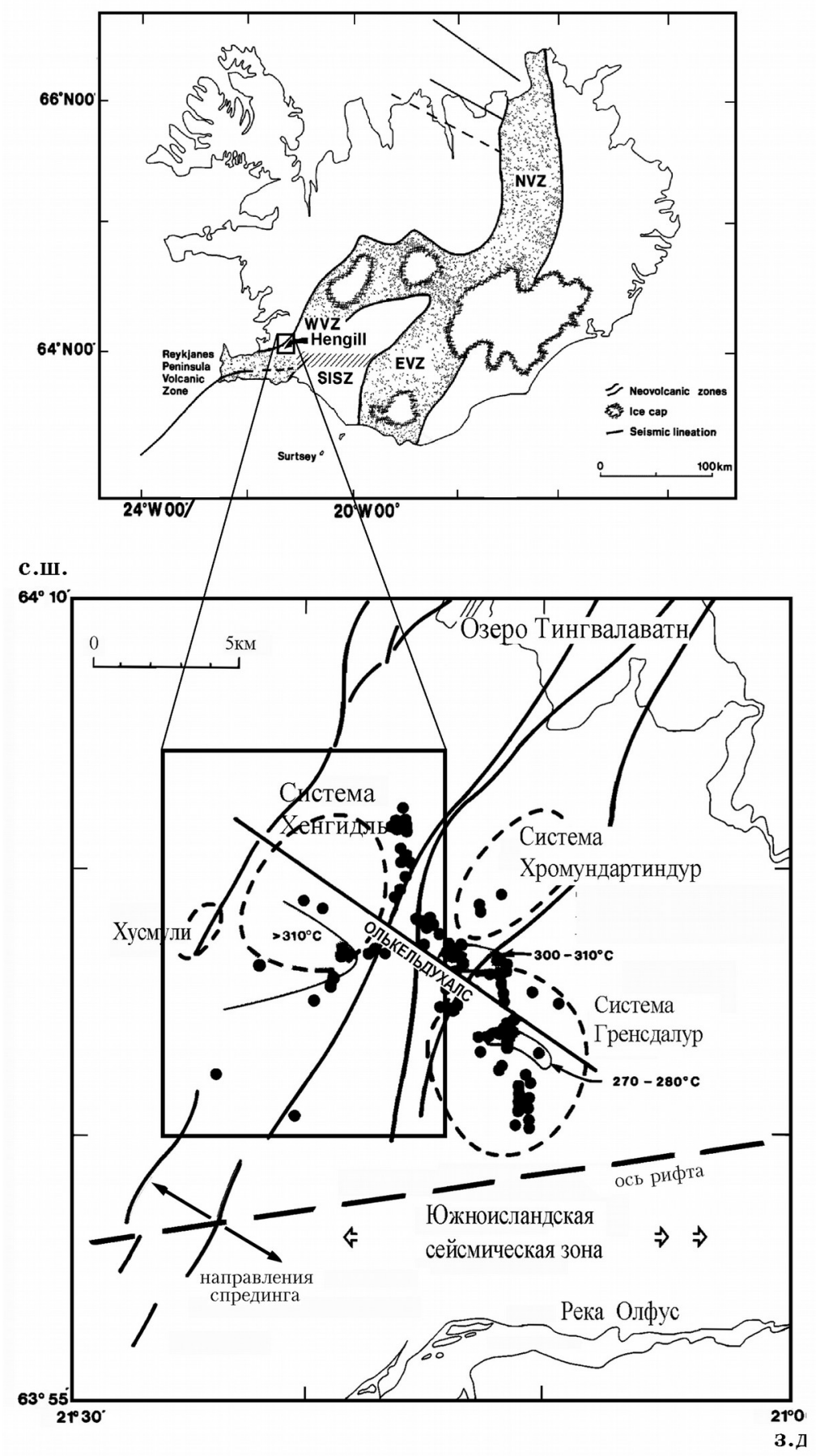




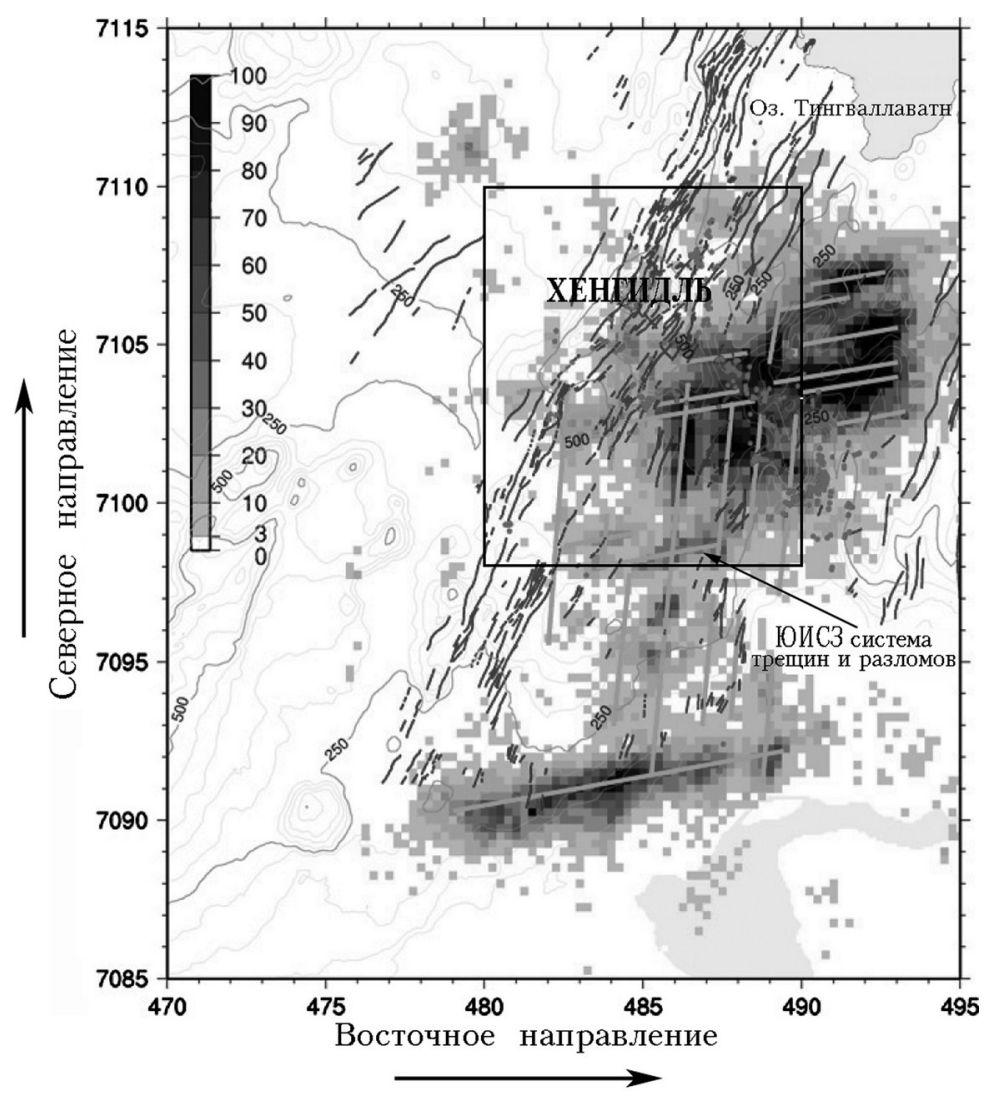




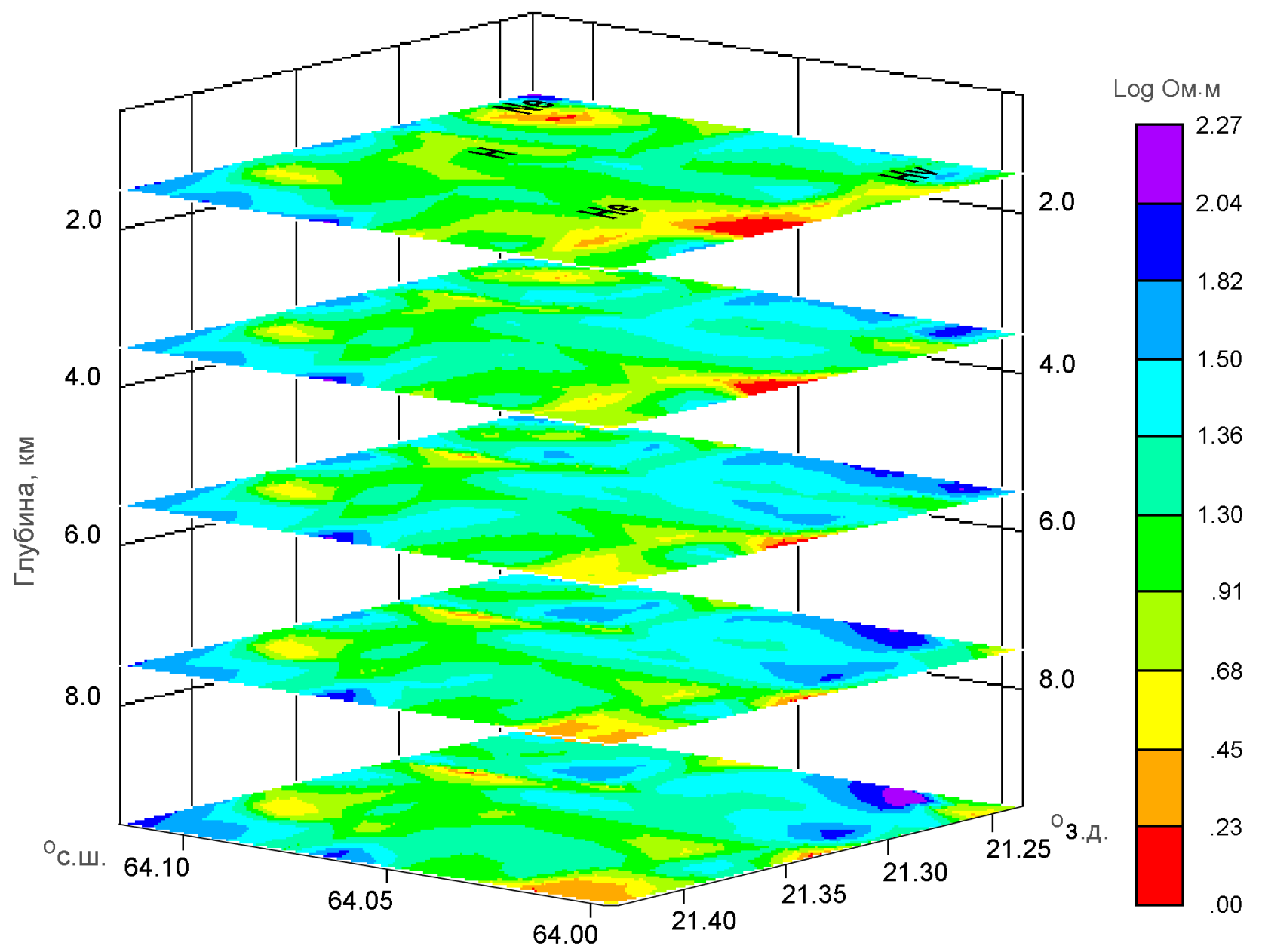



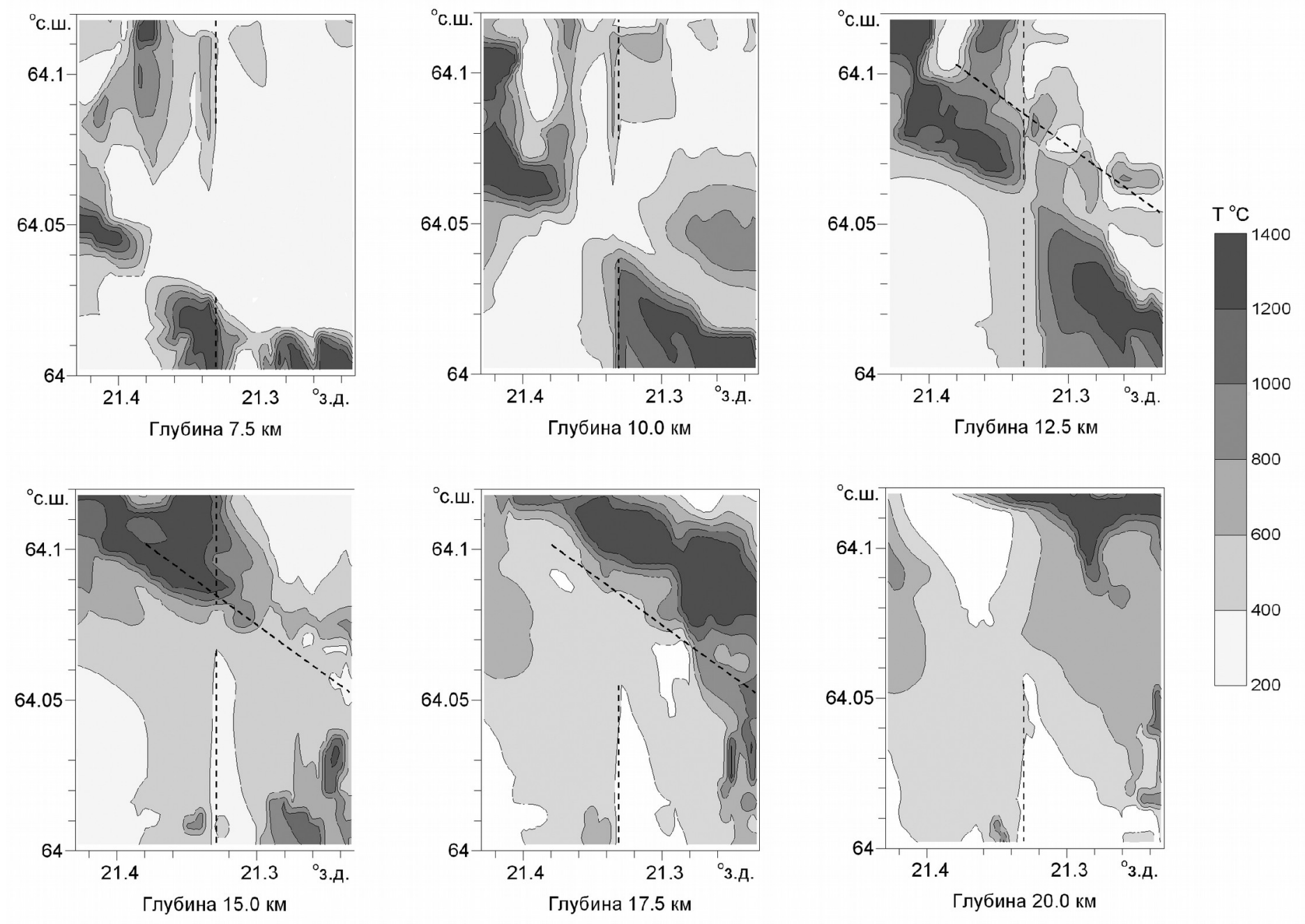

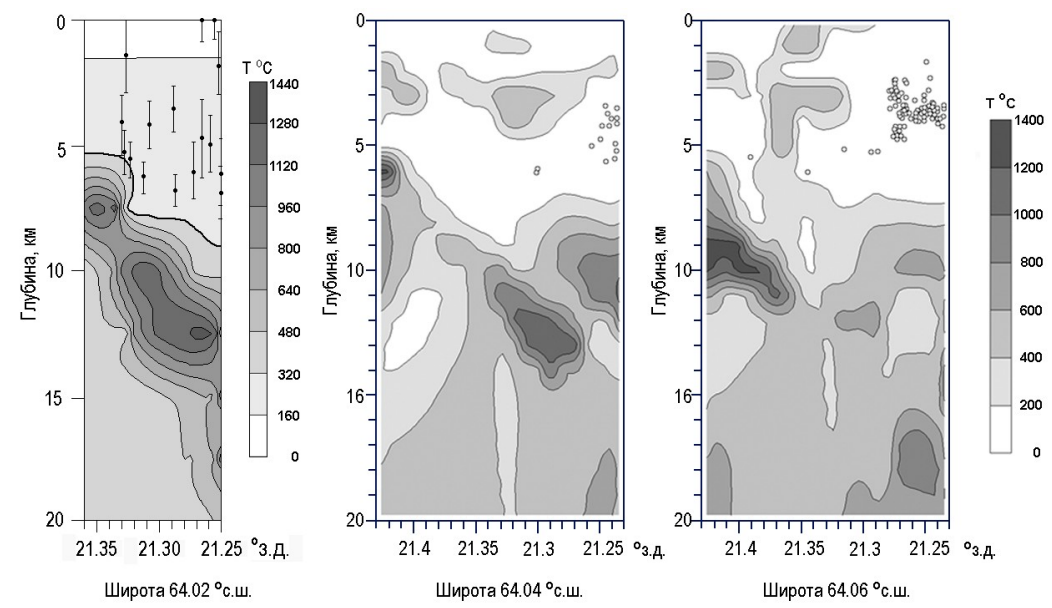


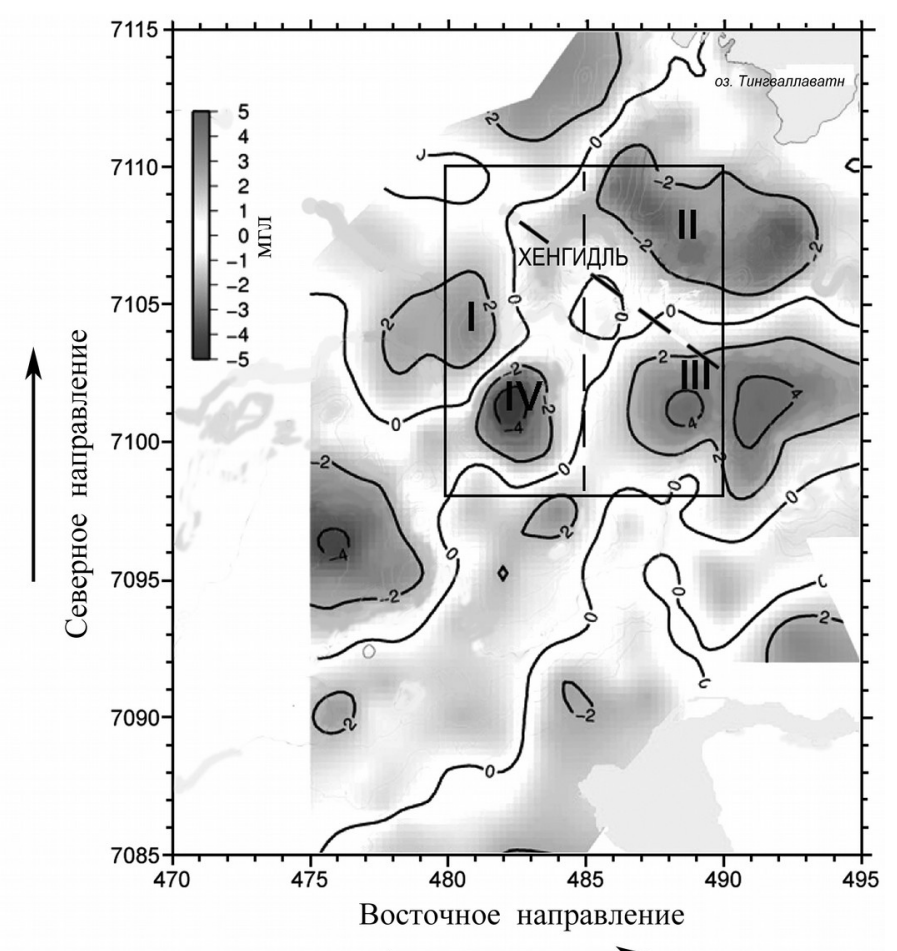




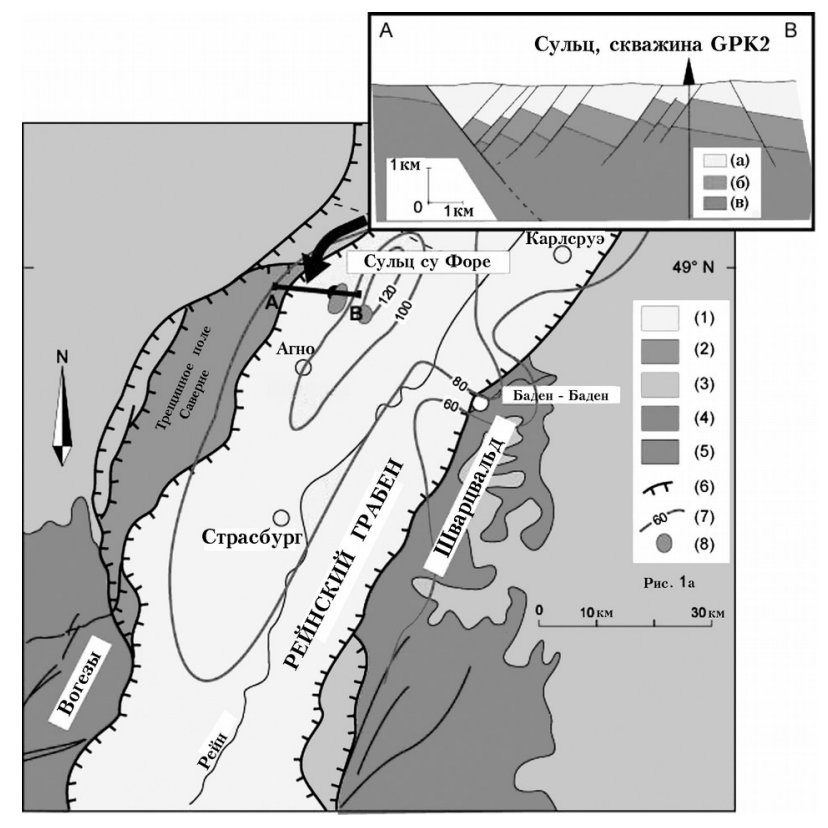




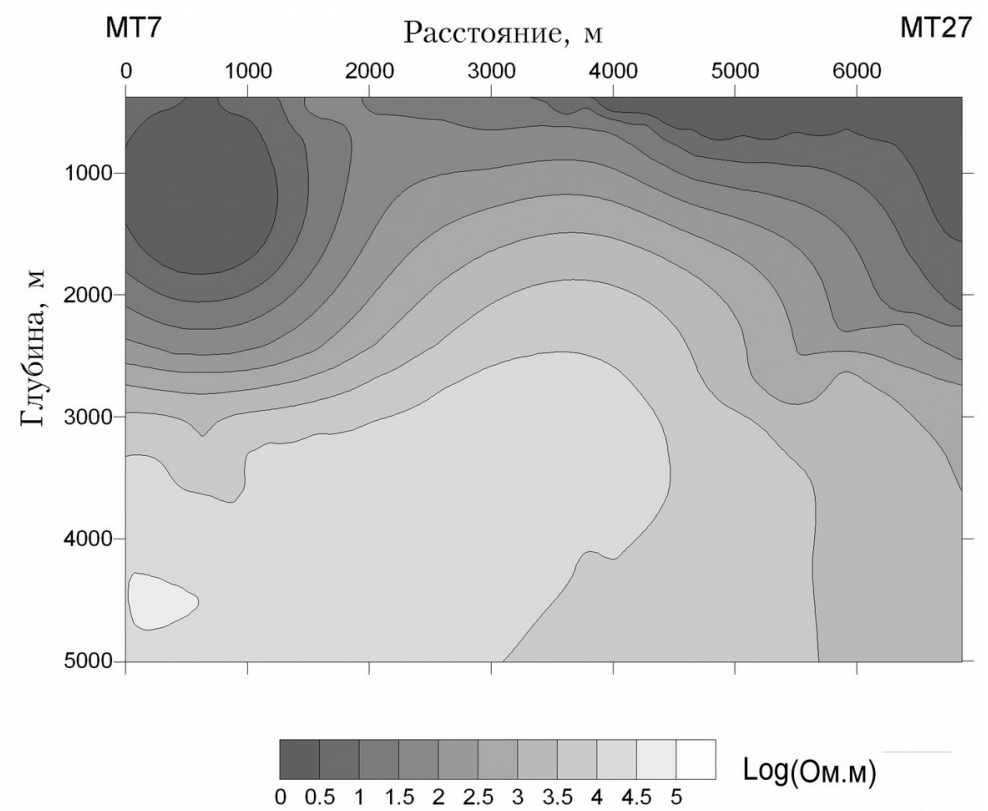




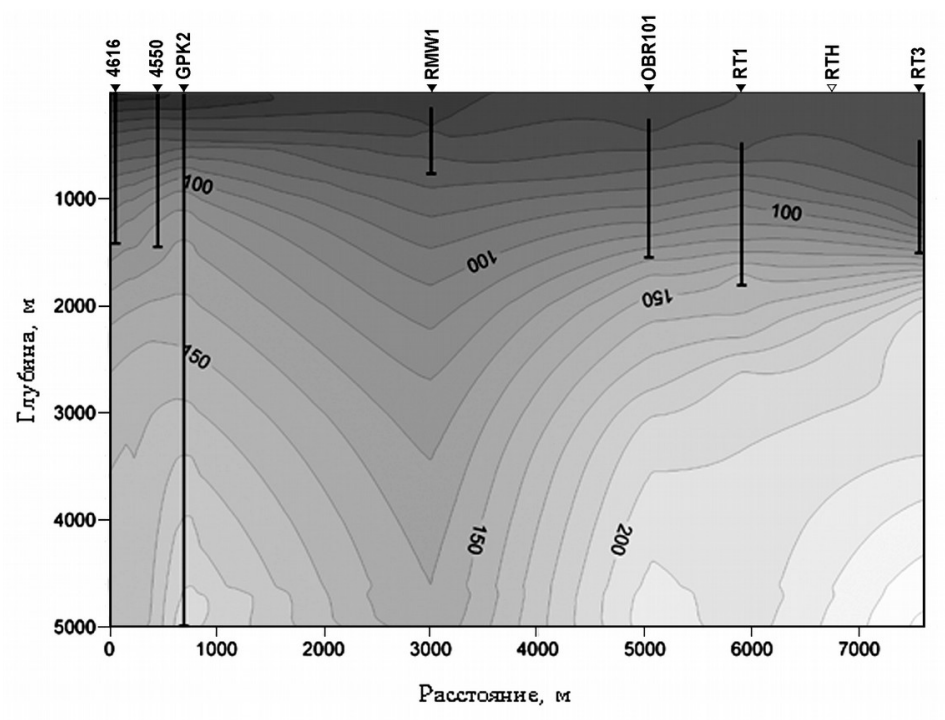

$\begin{array}{llllllllllllll}0 & 20 & 40 & 60 & 80 & 100 & 120 & 140 & 160 & 180 & 200 & 220 & 240 & \mathrm{~T}^{\circ} \mathrm{C}\end{array}$ 


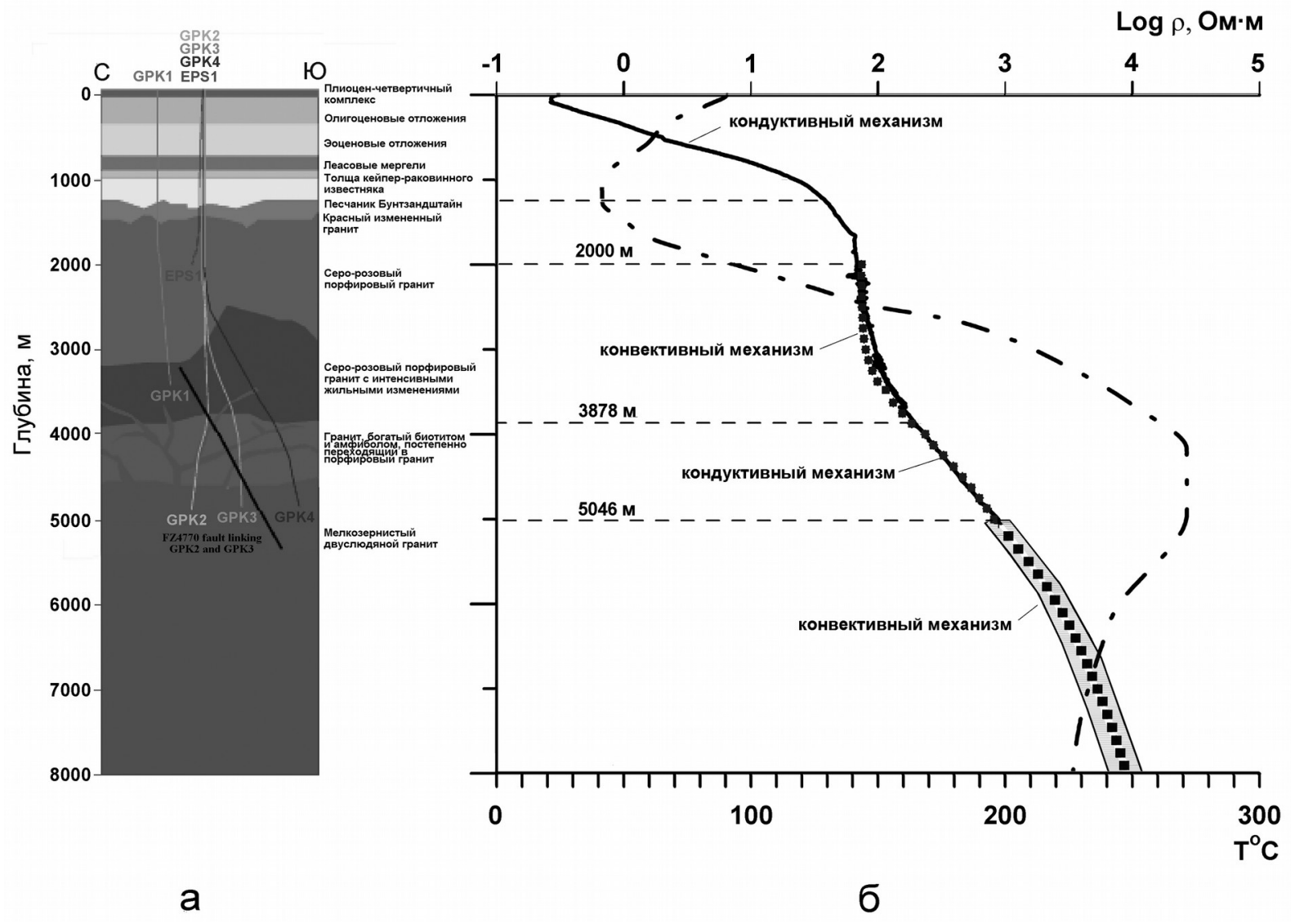

